Article

\title{
Preliminary Analysis of Life within a Former Subglacial Lake Sediment in Antarctica
}

\author{
David A. Pearce ${ }^{1,2,3, *}$, Dominic A. Hodgson ${ }^{2}$, Michael A. S. Thorne ${ }^{2}$, Gavin Burns ${ }^{2}$ and \\ Charles S. Cockell ${ }^{4}$
}

1 Faculty of Health and Life Sciences, University of Northumbria, Ellison Building, Newcastle upon Tyne NE1 8ST, UK

2 British Antarctic Survey, Natural Environment Research Council, High Cross, Madingley Road, Cambridge CB3 OET, UK; E-Mails: daho@bas.ac.uk (D.A.H.); mior@bas.ac.uk (M.A.S.T.); gavinburns@gmail.com (G.B.)

3 University Centre in Svalbard, Post Box 156, 9171 Longyearbyen, Norway

4 School of Physics and Astronomy, University of Edinburgh, James Clerk Maxwell Building, The King's Buildings, Edinburgh EH9 3JZ, UK; E-Mail: c.s.cockell@ed.ac.uk

* Author to whom correspondence should be addressed; E-Mail: david.pearce@northumbria.ac.uk; Tel.: +44-191-227-4517.

Received: 15 May 2013; in revised form: 5 July 2013 / Accepted: 8 August 2013 /

Published: 6 September 2013

\begin{abstract}
Since the first descriptions of Antarctic subglacial lakes, there has been a growing interest and awareness of the possibility that life will exist and potentially thrive in these unique and little known environments. The unusual combination of selection pressures, and isolation from the rest of the biosphere, might have led to novel adaptations and physiology not seen before, or indeed to the potential discovery of relic populations that may have become extinct elsewhere. Here we report the first microbiological analysis of a sample taken from a former subglacial lake sediment in Antarctica (Lake Hodgson, on the Antarctic Peninsula). This is one of a number of subglacial lakes just emerging at the margins of the Antarctic ice sheet due to the renewed onset of deglaciation. Microbial diversity was divided into 23.8\% Actinobacteria, 21.6\% Proteobacteria, 20.2\% Planctomycetes and $11.6 \%$ Chloroflexi, characteristic of a range of habitat types ( Overall, common sequences were neither distinctly polar, low temperature, freshwater nor marine). Twenty three percent of this diversity could only be identified to "unidentified bacterium". Clearly these are diverse ecosystems with enormous potential.
\end{abstract}


Keywords: Antarctica; bacteria; biodiversity; lake; polar; subglacial; sediment

\section{Introduction}

Since the first descriptions of Antarctic subglacial lakes [1,2], there has been a growing interest and awareness in the possibility that life will exist and potentially thrive in these unique and little known environments. Antarctic subglacial lake ecosystems have the potential to be one of the most extreme environments for life on Earth, with combined stresses of high pressure, low temperature, permanent darkness, low-nutrient availability and variable oxygen concentrations, and where the predominant mode of nutrition is most likely to be chemoautotrophic [3]. Subglacial lakes have now been identified across the majority of Antarctica [4] and the water they contain may play a crucial role in ice-sheet stability and the onset and discharge of ice streams [5]. As a result of significant and growing interest, three ambitious projects aimed to enter and retrieve samples from deep continental Antarctic subglacial lakes over the 2012/2013 Antarctic field season. Lake Vostok beneath the Eastern Antarctic plateau [6], Lake Ellsworth beneath more than $3 \mathrm{~km}$ of ice near the ice divide in the Ellsworth mountains [7-9] and the Whillans Ice Stream near the coast in the Ross Sea region [10]. It was in preparation for the direct access and sampling of Lake Ellsworth, that we sampled the subglacial sediment from Lake Hodgson, a former subglacial lake now emerging from the margins of the Antarctic Peninsula Ice Sheet. These sediments were deposited when the lake was in a subglacial stage, under a $500 \mathrm{~m}$ thick ice sheet [11]. Analyses of these sediments has enabled not only the first assessment of life in an Antarctic subglacial lake setting, but also an assessment of the potential limits of microbiological characterization technologies and optimization of the protocols that will be applied in analysing the water column and sediments of the deeper continental subglacial lake systems.

A number of studies to date have explored the potential for life in subglacial ecosystems and their analogues, for example, the microbial colonization of terrestrial surfaces exposed by glacier retreat [12], the characterization of life in supraglacial freshwater ecosystems [13], the retrieval of material from ice caves (for example, the fumarolic ice caves on Mount Erebus), within glaciers (for example, the Svartisen Subglacial Laboratory in Norway), in Iceland [14] and within the Greenland ice sheet [15]. Indeed, Antarctic glacier and Earth permafrost habitats are often regarded as terrestrial analogs of Martian polar subsurface layers [16].

In 2006, Gaidos et al. [17] sampled the anoxic bottom waters of a volcanic lake beneath the Vatnajökull ice cap in Iceland. The sample contained $5 \times 10^{5}$ cells per mL, and both FISH and PCR with domain-specific probes showed these to be essentially all bacteria, with no detectable archaea. They found that that the assemblage was dominated by a few groups of putative chemotrophic bacteria whose closest cultivated relatives used sulfide, sulfur or hydrogen as electron donors, and oxygen, sulfate or $\mathrm{CO}_{2}$ as electron acceptors. They found that hundreds of other phylotypes were also present but at lower abundance. Although a rarefaction analysis indicated that sampling did not reach saturation, FISH data limited the remaining biome to between $<10$ and $20 \%$ of all cells.

Having demonstrated that subglacial lakes beneath the Vatnajökull ice cap in Iceland hosted endemic communities of microorganisms adapted to cold, dark and nutrient-poor waters, 
Marteinsson et al. [18] extended this study to include samples of two related Icelandic subglacial lakes, a subglacial flood and a lake that was formerly subglacial but now partly exposed to the atmosphere. They found that the dominant taxa were closely related to cultivated anaerobes and microaerobes, and suggest that they might occupy unique metabolic niches in a chemoautolithotrophic ecosystem. They found that the lakes were dominated by a few bacterial taxa affiliated with the genera Acetobacterium, Geobacter, Sulfurospirillum, Sulfuricurvum and Desulfosporosinus. Thermus- and Paludibacter- affiliated sequences were also major components but differed in number across the two environments studied.

At Lake Vostok (Antarctica), Christner et al. [19] measured selected constituents within an accretion ice core to predict geomicrobiological conditions within the surface waters of the lake. Phylogenetic analysis of rRNA gene sequences in accretion ice formed over a deep portion of the lake revealed phylotypes that classified within the beta-, gamma-, and delta-Proteobacteria. D'Elia et al. [20,21], then isolated microbes from the accretion ice from the Firmicutes, Actinobacteria and alpha-Proteobacteria; these included Nitrobacter, Caulobacter, Cryobacterium, Arthrobacter, Nocardia, Kokuria, Micrococcus, Bacillus, Frankia, Terrebacter, Carnobacterium and Paenibacillus spp.

More recently, Rogers et al. [22] have published data from a metagenomic/metatranscriptomic analysis of Lake Vostok accretion ice. They found sequences that indicated the presence of thousands of species of microorganisms (94\% Bacteria, 6\% Eukarya, and two Archaea). The predominant bacterial sequences were closest to those from species of Firmicutes, Proteobacteria and Actinobacteria, while the predominant eukaryotic sequences were most similar to those from species of ascomycetous and basidiomycetous fungi. Based on the sequence data, they speculated that the lake appeared to contain a mixture of autotrophs and heterotrophs capable of performing nitrogen fixation, nitrogen cycling, carbon fixation and nutrient recycling.

All such studies have contributed significantly to a growing awareness of glacial ice as an ecosystem, yet direct access, sampling and analysis of an Antarctic subglacial lake ecosystem has only just been achieved. There are indications, however, that interesting microbial life might occur within such Antarctic subglacial lake ecosystems [23]. One is the study of the ice core [24] and the accretion ice above Lake Vostok [25,26], and the other on retrieved sediment from the base of the Kamb Ice Stream [27] in which viable microorganisms were recovered at low concentrations, and these covered five bacterial phylotypes which were a simplified version of those found in subglacial alpine and Arctic sediments and water. Here for the first time, we describe the microbiological analyses of an Antarctic subglacial lake sediment using a range of complementary technologies.

\section{Experimental Section}

\subsection{Sample Site}

Lake Hodgson on the Antarctic Peninsula $\left(72^{\circ} 00.549^{\prime} \mathrm{S}, 068^{\circ} 27.708^{\prime} \mathrm{W}\right.$ ) is comprehensively described in Hodgson et al. [11,28]. Briefly, in 2000, aerial reconnaissance of southern Alexander Island identified an extensive area of flat ice and snow within the cirque bounded by Citadel Bastion and Corner Cliffs (Figure 1). Further ground reconnaissance in 2001 established that this was the site of a perennially ice-covered freshwater lake, with dimensions of approximately $2 \times 1.5 \mathrm{~km}$, and a 93.4 $\mathrm{m}$ deep water column under 3.6-4.0 $\mathrm{m}$ of perennial lake ice. Cosmogenic isotope dating of glacial 
erratics and optically stimulated luminescence dating of raised lake shorelines showed that the ice mass over Hodgson Lake was at least $465 \mathrm{~m}$ thick before $10.5 \mathrm{ka}$ and $295 \mathrm{~m}$ thick before $13.5 \mathrm{ka}$ and has progressively thinned through the Holocene reaching an altitude of $c a .6 .5 \mathrm{~m}$ above the present lake ice sometime after $4.6 \mathrm{ka}$. Thick perennial ice cover persists over the lake today.

Figure 1. Hodgson Lake (A), one of a series of former subglacial lakes emerging from under the margins of the Antarctic Peninsula Ice Sheet. The adjacent catchment (B) is believed to contain another subglacial lake which is still under approximately $200 \mathrm{~m}$ of ice. Analyses of the catchment geomorphology and exposure age dating of glacially deposited erratic rocks show that Hodgson Lake was under at least $c a .500 \mathrm{~m}$ of ice at the end of the last glacial period. Sediments from this subglacial period are preserved in the bottom of the lake.

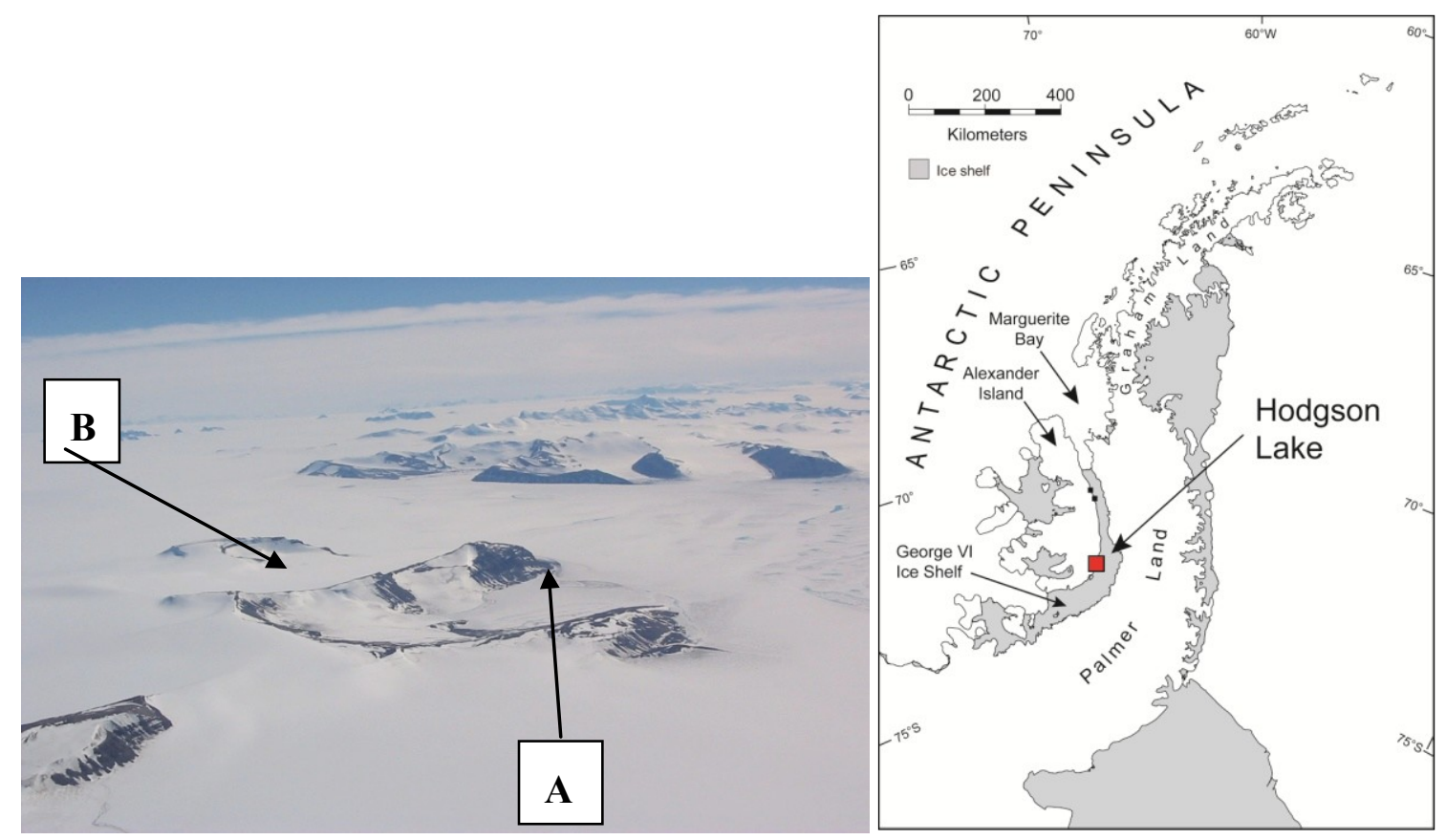

The thick perennial ice cover and the absence of a moat means that the lake water is isolated from the atmosphere and has a chemical composition consistent with subglacial melting of catchment ice. The lake is ultra-oligotrophic with low to undetectable levels of total nitrogen, nitrate, ammonium and phosphate [11], being within the ranges of those found in the accreted lake ice of subglacial Lake Vostok. Total organic carbon and dissolved organic carbon are present, but at lower concentrations than typically recorded in continental rain [11]. No organisms and no pigments associated with photosynthetic or bacterial activity were detected using light microscopy and high performance liquid chromatography [11]. Increases in $\mathrm{SO}_{4}{ }^{-2}$ and cation concentrations at depth and decline in $\mathrm{O}_{2}$ provide some evidence for sulphide oxidation and very minor bacterial demand upon $\mathrm{O}_{2}$ that result in small, perhaps undetectable changes in the carbon biogeochemistry. However, in general the chemical markers of life were inconclusive and abiotic processes such as the diffusion of pore waters into the lake from its benthic sediments are far more likely to be responsible for the increased concentrations of ions at depth.

Evidence of biological activity was sparse. Total organic carbon in the sediments varies from 0.2 to $0.6 \%$, and cannot be unequivocally linked to in situ biological activity as comparisons of $\delta^{13} \mathrm{C}$ and $\mathrm{C} / \mathrm{N}$ 
values with local reference data suggest that much of it is derived from the incorporation of carbon in catchment soils and gravels and possibly old $\mathrm{CO}_{2}$ in meteoric ice. Further details on the limnology are described in [11].

\subsection{Sample Recovery}

A $3.8 \mathrm{~m}$ sediment core was extracted at a depth of $93.4 \mathrm{~m}$ below the ice surface inside a virkon sterilized and polycarbonate lined core barrel. When taken all core samples remained within the core liners and were immediately frozen until sub-sampling in a clean class II microbiological safety cabinet in Cambridge. Gloves were used at all times and instruments used in laboratory manipulations were autoclaved. Four stratigraphic zones (A-D) were identified. A chronological model was developed using a combination of radiocarbon, optically stimulated luminescence (OSL), and relative palaeomagnetic intensity dating [28]. A well-defined magnetic polarity reversal event was provisionally assigned at ca $165 \mathrm{~cm}$ in the lake sediments to the Mono Lake excursion, a global palaeomagnetic time marker which occurred between 31,500 and 33,300 years ago, whilst OSL measurements suggested that material incorporated into the basal sediments might date to $93,000 \pm 9000$ years ago. The chronological model suggests that zones A-C were deposited between Marine Isotope Stages 5-2 (i.e., spanning the last glacial) and zone D during Marine Isotope Stage 1 (the Holocene).

The palaeolimnological record tracks changes in the subglacial depositional environment linked principally to changing glacier dynamics and mass transport and indirectly to climate change. There was no evidence of overriding glaciers being in contact with the bed reworking the stratigraphy or removing this sediment. This suggests that the lake existed in a subglacial cavity beneath overriding ice during the last glacial and Last Glacial Maximum (LGM, approximately 26,500-19,000 years ago). In zone $\mathrm{D}$ there is a transition to finer grained sediments characteristic of lower energy delivery coupled with a minor increase in the organic content attributed either to increases in allocthonous organic material being delivered from the deglaciating catchment, a minor increase in within-lake production or to an analytical artefact associated with an increase in the clay fraction.

The $3.8 \mathrm{~m}$ core was subdivided into a series of depth sections of $19.6 \mathrm{~cm} \times 2.8 \mathrm{~cm}$ cylinders (Figure 2). Five depth samples were taken from these subglacial sediment sections $(\mathrm{A}, 2 \times \mathrm{B}, \mathrm{C}$ and $\mathrm{D}$ in the core) in the class II microbiological safety cabinet and used to trial a range of methods for life detection in Antarctic subglacial environments. External layers were removed with a sterile scalpel following surface rinsing with ethanol. $0.5 \mathrm{~cm}$ was removed from the top of the core and around the circumference and discarded. A $1 \mathrm{~cm}$ disc was then removed from the core and homogenized. This technique was developed on sterile sediment material that had been surface contaminated with E. coli, in order to determine the optimal conditions for sediment removal whist excluding any possibility of surface contamination from outside the core. The relationship between the zone boundaries and samples analysed were: Subglacial sediments: zone A-(includes sample CB 3) 300-320 cm, zone B-(includes sample CB 3Z) 280-300 cm and 260-280 cm (including sample CB 3Y), zone C-(includes sample CB 3X) 240-260 cm and Holocene sediments (i.e., during ice thinning over site and possibly some light penetration) zone D-(includes the $0-1 \mathrm{~cm}$ ) surface sediment sample. Holocene sediments were not used in the 454 pyrosequencing analysis. 
Figure 2. A schematic representation of sample depths (not to scale).

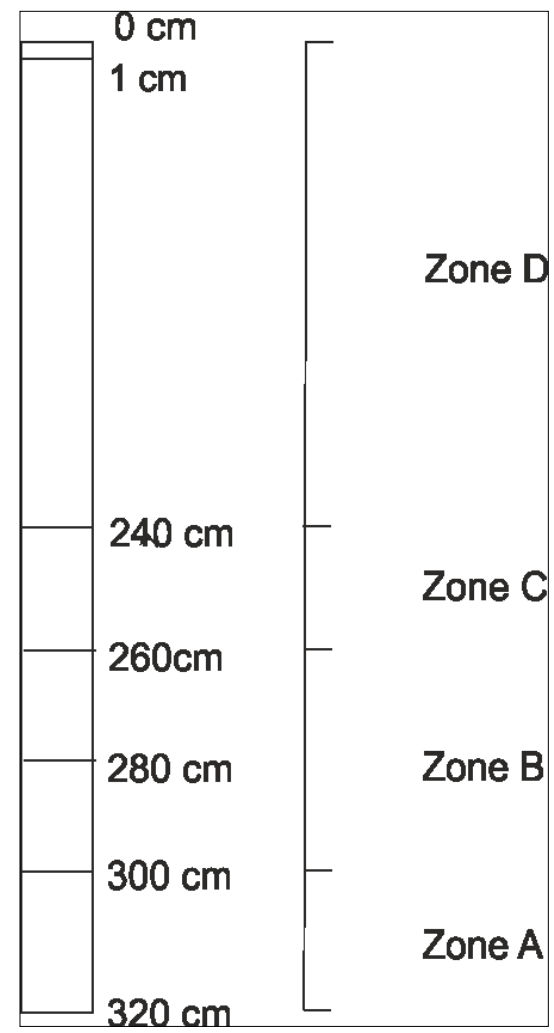

\subsection{Microscopy (DAPI Staining)}

An initial assessment of bacterioplankton population density was made modifying the method of Porter and Feig [29] by streaking $0.02 \mathrm{~g}$ of sediment across a microscope slide and incubating at room temperature for $5 \mathrm{~min}$ with Vectashield mounting medium containing $5 \mathrm{mg} \mathrm{mL}{ }^{-1}, 4$-6-diamidino-2phenylindole (DAPI). Four $0.02 \mathrm{~g}$ sediment samples were then diluted 1:10 in sterile, $0.2 \mathrm{~mm}$ filtered sterile Milli-Q water and phosphate buffered saline PBS (PBS; $10 \mathrm{mM}$ sodium phosphate [pH 7.2], $130 \mathrm{mM} \mathrm{NaCl}$ [pH 7.4]) and homogenized briefly using a vortex mixer. Cells were harvested by vacuum-filtration $(\sim 30 \mathrm{kPa})$ of the suspension through a $25 \mathrm{~mm}, 0.22 \mathrm{~mm}$, black, polycarbonate filter membrane (Porectics, Osmotics Inc., Denver, CO, USA). Cell fixation was performed directly on the filter membrane using $2 \mathrm{~mL}$ paraformaldehyde [4\% wt/vol] (Sigma-Aldrich, Poole, UK) for $30 \mathrm{~min}$ followed by three washes $(5 \mathrm{~mL})$ with Milli-Q water and PBS to remove excess fixative. Filters were stained with DAPI ( $\left.5 \mathrm{mg} \mathrm{mL}^{-1}\right)$ for $5 \mathrm{~min}$, rinsed twice with sterile Milli-Q water and PBS (5 mL), air dried and mounted in CitiFluor (CitiFluor Ltd., Canterbury, UK). Enumeration was conducted using a Leitz Labalux epifluorescence microscope fitted with a $50 \mathrm{~W}$ mercury, high-pressure lamp, UV excitation and a filter set for DAPI (340-380 nm excitation filter, $400 \mathrm{~nm}$ beam splitter, and $430 \mathrm{~nm}$ barrier). A minimum of 2500 cells were counted per sample from $>50$ randomly selected fields of view across each slide. Bacterial cell counts were expressed as mean number of cells per gram of wet sediment ( \pm 1 standard deviation; $\mathrm{SD})$. 


\subsection{Microscopy (Fluorescence in Situ Hybridization)}

An initial assessment of bacterioplankton population diversity was made by fluorescence in situ hybridization (FISH). $0.02 \mathrm{~g}$ of sediment was suspended in $5 \mathrm{~mL}$ PBS. Each sample was briefly vortexed and filtered through a black polycarbonate $0.2 \mu \mathrm{m}$ screen membrane filter (Poretics, Livermore, CA, USA). Cells were fixed with $2 \mathrm{~mL}$ of $4 \%$ paraformaldehyde in PBS for 30 min (or 2\% glutaraldehyde). A gentle vacuum was then applied and cells rinsed, initially in $5 \mathrm{~mL}$ PBS, then in $5 \mathrm{~mL}$ distilled water. Filters were removed from the filtration apparatus, air-dried, placed on a glass microscope slide and stored at $-20{ }^{\circ} \mathrm{C}$. All preservation and hybridization conditions are selected to minimize impact on the integrity and characteristics of cells. $16 \mu \mathrm{L}$ of hybridization buffer containing one of eleven different in situ hybridization probes was added to each of the samples and incubated at $46{ }^{\circ} \mathrm{C}$ for $90 \mathrm{~min}$ in a closed hybridization tank. The atmosphere in the hybridization tank was saturated from excess hybridization buffer on filter papers at the base of the tank. Each slide was then rinsed with $20 \mathrm{~mL}$ pre-warmed washing buffer at $48{ }^{\circ} \mathrm{C}$ over a period of $15 \mathrm{~min}$.

The eleven, 5'CY-3-labelled, oligonucleotide probes (VH Bio Ltd, Gateshead, UK) used were: EUB338 Eubacteria [30] ACT CCT ACG GGA GGC AGC; ARCH915 Archaea [31] Archaeal 16S rRNA (915-934) GTG CTC CCC CGC CAA TTC CT; ALF968 Most Alphaproteobacteria 16S rRNA (968-986) and most Pelobacter/Geobacter spp. [32] GGT AAG GTT CTG CGC GTT; GAM42a Gammaproteobacteria [33] GCC TTC CCA CAT CGT T; BET42a Betaproteobacteria [34] 23S rRNA (1027-1043) GCC TTC CCA CTT CGT TT; CF319 Cytophaga/Flavobacterium cluster of the Bacteroidetes phylum [34] (16S rRNA (319-336) TGG TCC GTG TCT CAG TAC; SRB385 Sulphate-reducing Deltaproteobacteria [30] 16S rRNA (385-402) CGG CGT CGC TGC GTC AGG; ANME-1-350 for archaeal methanogens group ANME-1 [35] AGT TTT CGC GCC TGA TGC; HGC236 Actinobacteria [36] 16S, 235-253 Gram positive high G + C content AAC AAG CTG ATA GGC CGC and LGC354 Firmicutes [37] 16S rRNA (354-371) Gram positive low G + C content TGG AAG ATT CCC TAC TGC. A negative control for non-specific binding was also made with the 5'CY3-labeled probe NON-EUB338 (Bacterial 16S rRNA, 338-355) GCT GCC TCC CGT AGG AGT [38], which has the complementary (antisense) sequence to probe EUB338. A positive control after hybridization was also performed by staining a sub set of samples with DAPI. For this procedure, $100 \mu \mathrm{L}$ of DAPI ( $5 \mathrm{mg} \mathrm{mL}^{-1}$ ) was added for $5 \mathrm{~min}$, rinsed twice with sterile Milli-Q water and PBS $(5 \mathrm{~mL})$, air dried and observed as described above. This procedure was used to check that the signal observed by FISH corresponded to microorganisms. A second positive hybridization control involved the addition of E.coli cells to a sample and staining with EUB338. Each probe was added at a final concentration of $50 \mathrm{ng} \mathrm{mL}^{-1}$ to $250 \mu \mathrm{L}$ hybridization solution $(0.9 \mathrm{M} \mathrm{NaCl}, 20 \mathrm{mM}$ Tris- $\mathrm{HCl}(\mathrm{pH} 7.4)$, $0.01 \%$ SDS) containing 10\% v/v formamide (for EUB338, NON338), 20\% (for ALF968, HGC236, LGC354) and 35\% v/v formamide (for GAM42a, BET42, PLA42, CF319, ARCH915, ANME-1) with $20 \mu \mathrm{L}$ hybridization solution. Cells were incubated in a humid atmosphere $\left(46^{\circ} \mathrm{C}, 90 \mathrm{~min}\right)$ and rinsed twice with $5 \mathrm{~mL}$ warmed wash buffer (20 mM Tris-HCl, $5 \mathrm{mM}$ EDTA, 0.01\% SDS and $70 \mathrm{mM} \mathrm{NaCl}$ ). Air-dried cells were mounted in Vectashield (Vector Labs, Burlingame, CA, USA) and enumerated by epifluorescence microscopy. The filters are placed on slides, air-dried, mounted with Vectashield to minimize bleaching and viewed at $\times 1250$, under oil immersion, with a Leitz Labalux epifluorescence microscope equipped with a $50 \mathrm{~W}$ mercury lamp and a CY3 filter set (filter set 41007A, Chroma, 
Bellows Falls, VT, USA). The presence or absence of hybridization with each group specific probe was noted over replicate samples. Following this initial assessment, the three probes with the best hybridization were selected for further investigation. A series of three replicate slides were prepared for each sample sediment sample and treated as described above. This time a minimum of 1000 DAPIstained bacterial cells within 10-20 randomly selected fields of view, or 250 cells in total were enumerated. The mean number of hybridized cells $\mathrm{g}^{-1}$ wet sediment was estimated for each sample.

\subsection{Microscopy (Scanning Electron Microscopy)}

Samples of sediment were examined by Scanning Electron Microscopy (SEM) from each of the five depth sections. Samples of dehydrated sediment were fixed to aluminium stubs with carbon impregnated glue. Samples were carbon coated (15-20 nm thickness) and examined in secondary mode at $20 \mathrm{kV}$ accelerating voltage and 7-15 mm working distance using a Quanta 3D dual beam FIBSEM (FEI, OR, USA) [39,40]. A minimum of four photographs were taken for each section.

\subsection{Direct Culture}

Samples of sediment $(\sim 0.1 \mathrm{~g})$ were aseptically added to $10 \mathrm{~mL}$ dd $\mathrm{H}_{2} \mathrm{O}$ and shaken until the sediment was fully dispersed. Using a pipette, $200 \mu \mathrm{L}$ of the suspension was removed and spread evenly on the surface of agar plates. Negative controls of autoclaved sediment, and clean $\mathrm{dd}_{2} \mathrm{O}$ were also prepared to allow for the potential for contamination during handling procedures. Agar plates of the following types were prepared: $0.001,0.01$ and $0.1 \% \mathrm{wt} / \mathrm{vol}$ tryptone soya broth (Oxoid, Basingstoke, UK). 0.001 and $0.01 \% \mathrm{wt} / \mathrm{vol}$ yeast extract (Oxoid, Basingstoke, UK) and 0.001 and $0.01 \%$ yeast extract in a minimal salts medium [41]. The $\mathrm{pH}$ of all plates was 7-7.5. All plates were made with 2\% agar (Oxoid, Basingstoke, UK; Bacteriological Agar No. 1), which was washed according to the method of Ryan [42]. Plates were incubated under aerobic conditions at 21 and $4{ }^{\circ} \mathrm{C}$ for three months and observed during this time for colony formation.

\subsection{DNA Extraction and PCR Amplification}

Samples of frozen surface sediment $(\sim 0.5 \mathrm{~g})$ were removed from sediment cores for DNA extraction. DNA extractions were carried out using the PowerSoil DNA isolation kit (Mo Bio, Carlsbad, CA, USA) following the manufacturers standard protocol. The resulting DNA was quantified using a Nanodrop spectrophotometer (Thermo Fisher Scientific, Waltham, MA, USA). Each extraction from $0.5 \mathrm{~g}$ sediment produced $\sim 250 \mathrm{ng}$ of DNA in $100 \mu \mathrm{L}$ nuclease free water.

16S RNA gene amplification was carried out on sediment DNA obtained from the four depth sections A-C (15 ng input DNA) using forward primer 787f ATT AGA TAC CCN GGT AG and reverse primer 1492Rm GNT ACC TTG TTA CGA CTT at an annealing temperature of $50{ }^{\circ} \mathrm{C}$ to produce amplicons of $705 \mathrm{bp}$. PCR reactions were $15 \mu \mathrm{L}$ and contained $1 \times$ PCR buffer, $2.0 \mathrm{mM}$ $\mathrm{MgCl}_{2}, 0.25 \mathrm{mM}$ dNTPs, $0.25 \mathrm{mM}$ each primer, 0.4 Units BioTaq (Bioline, London, UK) and ca. 15 ng template DNA. For Thermocycling: $1 \times 95{ }^{\circ} \mathrm{C}$ for $50 \mathrm{~s} ; 30 \times 95{ }^{\circ} \mathrm{C}$ for $20 \mathrm{~s}, 50{ }^{\circ} \mathrm{C}$ for $30 \mathrm{~s}, 72{ }^{\circ} \mathrm{C}$ for $3 \mathrm{~min}\left(\operatorname{ramp} 72{ }^{\circ} \mathrm{C}\right.$ at $\left.0.3{ }^{\circ} \mathrm{C} \mathrm{s}^{-1}\right) ; 1 \times 72{ }^{\circ} \mathrm{C}$ for $10 \mathrm{~min}$. Multiple PCR amplifications (24 in total) were cleaned and pooled to produce $900 \mathrm{ng}$ of $16 \mathrm{~S}$ enriched DNA for 454 library preparation. 


\subsection{Pyrosequencing}

An amplicon library was generated using the Rapid Library Preparation kit and following the manufacturer's recommendations in the GS FLX Titanium Series Rapid Library Preparation Method Manual (Roche). Briefly, the PCR amplicons were purified using AMPure beads (Agencourt Bioscience Corporation, Beverly, MA, USA), adaptors were blunt-end ligated to the fragment and the dsDNA amplicon library was quantitated via fluorometry using Quanti-iT Pico Green reagents (Invitrogen, Carlsbad, CA, USA). The library was then subjected to clonal amplification by emulsion PCR followed by pyrosequencing on a 454 GS FLX sequencer according to the manufacturer's instructions (NEB NextQuick 454 library prep kit E6090).

\subsection{Data Analysis}

The 454 pyrosequencing sequencing reads were trimmed to remove library preparation related and low quality sequence using both Geneious [43] and Mothur [44] and systematic artifacts resulting from the 454 pyrosequencing technology were removed [45]. Quality trimmed sequences greater than $100 \mathrm{bp}$ in length were submitted to the MG-RAST [46] metagenomic server where they were analysed against the SILVA [47], Greengenes [48] and RDP [49] 16S ribosomal DNA databases using an e-value cutoff of $1 \mathrm{e}-10$ with minimum identity cutoff of $60 \%$ and a minimum alignment length cutoff of 15. Alpha diversity, based on an information theoretic metric, was calculated from the homology assignments of the 16S RNA gene sequences, as outlined in the MG-RAST pipeline.

\section{Results and Discussion}

\subsection{Microscopy}

Microbial counts direct from the pore water gave a minimum cell density of $>10^{3}$ DAPI stained cells $\mathrm{mL}^{-1}$ which was equivalent to $5 \times 10^{4}$ cells $\mathrm{g}^{-1}$ wet sediment. A word of caution is necessary here. When retrieving sediment samples remotely using a sediment corer, it is not possible to know the density of the sediment material in situ, as some compaction of the sample may occur during coring. When retrieving the core, this compaction may be somewhat reduced and when frozen and defrosted water may be excluded. Hence, all calculations based on cell number per $\mathrm{g}^{-1}$ dry or wet sediment refer to the sample material itself and not the environmental context (although they may be the same). The surface sediment ex-situ contained $4.4( \pm 0.6) \times 10^{7}$ cells $\mathrm{g}^{-1}$ wet weight sediment, $240-260 \mathrm{~cm}$ $1.2( \pm 0.7) \times 10^{7}, 260-280 \mathrm{~cm} 1.6( \pm 0.8) \times 10^{7}$ and $280-300 \mathrm{~cm} 4.1( \pm 0.1) \times 10^{7}$. Positive hybridizations were obtained with FISH probes EUB338, ALF968, BET42a, GAM42a, CF319 and HGC236. No hybridizations were detected for LGC354, SRB385, ANME-1-350, ARCH915 and the control NON338 probe. Hybridizations with EUB338 were surface $3.3( \pm 0.4) \times 10^{7}, 240-260 \mathrm{~cm}$ $1.0( \pm 0.3) \times 10^{7}, 260-280 \mathrm{~cm} 1.3( \pm 0.3) \times 10^{7}$ and $280-300 \mathrm{~cm} 2.4( \pm 0.4) \times 10^{7}$. Hybridizations with GAM42a were surface $1.4( \pm 0.1) \times 10^{7}, 240-260 \mathrm{~cm} 7.0( \pm 2.8) \times 10^{6}, 260-280 \mathrm{~cm} 7.4( \pm 1.4) \times 10^{6}$ and $280-300 \mathrm{~cm} 1.1( \pm 0.3) \times 10^{7}$. Hybridizations with BET42a were surface $1.3( \pm 0.3) \times 10^{7}$, $240-260 \mathrm{~cm} 3.1( \pm 3.6) \times 10^{6}, 260-280 \mathrm{~cm} 3.9( \pm 1.4) \times 10^{6}$ and $280-300 \mathrm{~cm} 9.4( \pm 2.2) \times 10^{6}$. No visible cells were observed from fifteen independent scanning electron micrographs. 


\subsection{Direct Culture}

A total of 20 isolates were obtained from the surface sediment sample (zone D). No growth was observed from samples from the deeper sediment sections (zones A-C). The surface cultures were: two Streptomyces sp. (Streptomyces sp. AcH 505 and Streptomyces beijiangensis NBRC 100044), three Sporosarcina sp. (2 Sporosarcina sp. NP23 and Sporosarcina sp. Tibet-S2a1) and fifteen Arthrobacter sp. (6 Arthrobacter sp. Marine-33, 3 Arthrobacter sp. S22237, Arthrobacter tumbae strain KOPRI_22204, 2 Arthrobacter sp. RUGL6-4, Arthrobacter sp. A5ATB, Arthrobacter sp. VTT E-052916 16S and an uncultured Arthrobacter sp. clone GASP-WA1W2_G12).

\subsection{Pyrosequencing}

High throughput sequencing of 16S rRNA genes amplified from extracted environmental DNA generated 90,795 reads, which resulted in 82,841 sequences after selection on quality and length, totaling 31,581,481 base pairs (bps) with an average read length of 369 bps. 80,788 of these sequences (97.5\%) were identified by MG-RAST as ribosomal RNA. The sequences are available through Genbank (accession number SRA067787).

\section{4. $S S U$}

These were divided into $23.8 \%$ Actinobacteria, 21.6\% Proteobacteria, 20.2\% Planctomycetes, 11.6\% Chloroflexi, 7.2\% Spirochaetes, 5.3\% Firmicutes, 4\% Chlamydiae, 2.2\% Nitrospirae and 2.15\% Bacteroidetes. Only $0.03 \%$ were Cyanobacteria and $21.3 \%$ were unclassified but derived from Bacteria (Table 1). The top matches (where abundance was $>1000$ sequences or $>1 \%$ of the total sequence number) were to uncultured bacteria (uncultured bacterium $12.3 \%$, uncultured delta proteobacteria 6.8\%; unassigned 5.4\%; unidentified 2.8\%; uncultured Dehalococcoides sp. 2.5\%; uncultured proteobacteria $2.3 \%$ ). The most abundant matches to named groups were: Pirellula staleyi 9.7\%; Thermobaculum terrenum 5.0\%; Rhodopirellula baltica 2.98\%; Dehalococcoides ethenogenes 2.88\%; Coptotermes formosanus 2.6\%; Spirochaeta aurantia 2.4\%; Spirochaeta thermophila 2.4\%; Methylococcus capsulatus 2.1\%; Thermomicrobium roseum 1.4\%; Actinosynnema mirum 1.4\%; Mycobacterium leprae 1.3\%; Streptomyces microflavus 1.3\%; Protochlamydia naegleriophila 1.3\%; Leptospirillum ferrodiazotrophum 1.2\%; Conexibacter woesei 1.1\% and Amycolatopsis sp. GY182 $1.1 \%$ (Table 1). A relatively low number of sequences were from the Archaea (375) and 50\% of these were from Candidatus Nitrososphaera gargensis, A further $25 \%$ were from Candidatus Nitrosocaldus yellowstonii and uncultured archaea. The remaining 25\% were derived from the Thermoprotei, Methanomicrobia, Thermoplasmata, Methanobacteria and Halobacteria. The Simpsons diversity index was 0.96 for this data set indicating a high diversity. The Chao diversity estimator was 148.5 [50], representing a coverage of $58.6 \%$.

\subsection{RDP Analysis}

The top matches using the RDP database (where abundance was $>1000$ sequences or $>1.3 \%$ of the total sequence number) were to uncultured bacteria (uncultured bacterium 17\%, unassigned 3.5\%, uncultured delta proteobacteria $8.7 \%$; uncultured proteobacteria $2.98 \%$; uncultured Dehalococcoides 
sp. 3.1\%). The most abundant matches to named groups were: Pirellula staleyi $12.4 \%$, Rhodopirellula baltica 3.7\%; Spirochaeta aurantia 3.0\%; Spirochaeta thermophila 3\%; Thermobaculum terrenum 3\%; Thermomicrobium roseum 2.1\%; Streptomyces microflavus 1.7\%; Protochlamydia naegleriophila 1.6\%; Leptospirillum ferrodiazotrophum 1.4\% and Amycolatopsis sp. GY182 1.4\%. The Simpsons diversity index was 0.94 for this data set indicating a high diversity. The Chao diversity estimator was $151[50]$ representing a coverage of $57.6 \%$.

Table 1. Sequences obtained to genus and species level, where frequency was $>200$ hits of individual 454 reads (Abbreviations: avg. = average; ident. = identity).

\begin{tabular}{|c|c|c|c|c|}
\hline Organism & Abundance & $\begin{array}{c}\text { Avg. eValue } \\
\text { exponent }\end{array}$ & Avg. \% ident. & Avg. align length \\
\hline uncultured bacterium & 12424 & -71.72 & 99.46 & 139.44 \\
\hline Pirellula staleyi & 9869 & -39.89 & 99.83 & 83.06 \\
\hline uncultured delta proteobacterium & 6903 & -48.08 & 99.72 & 97.44 \\
\hline unassigned & 5481 & -65.37 & 99.62 & 127.16 \\
\hline Thermobaculum terrenum & 5083 & -43.62 & 99.64 & 89.4 \\
\hline Rhodopirellula baltica & 3021 & -32.16 & 99.61 & 70.38 \\
\hline Dehalococcoides ethenogenes & 2917 & -35.55 & 98.97 & 78.98 \\
\hline unidentified & 2859 & -43.24 & 99.08 & 91.3 \\
\hline Coptotermes formosanus & 2627 & -34.79 & 99.59 & 75.26 \\
\hline uncultured Dehalococcoides sp. & 2494 & -31.23 & 100 & 67.85 \\
\hline Spirochaeta aurantia & 2408 & -35.59 & 99.95 & 74.67 \\
\hline Spirochaeta thermophila & 2401 & -37.59 & 100 & 78.31 \\
\hline uncultured proteobacterium & 2356 & -52.95 & 99.91 & 104.68 \\
\hline Methylococcus capsulatus & 2113 & -41.94 & 99.42 & 86.89 \\
\hline Thermomicrobium roseum & 1429 & -33.81 & 99.6 & 73.24 \\
\hline Actinosynnema mirum & 1394 & -62.16 & 94.94 & 135.81 \\
\hline Mycobacterium leprae & 1336 & -56.61 & 95.66 & 123.56 \\
\hline Streptomyces microflavus & 1333 & -38 & 100 & 79.33 \\
\hline Protochlamydia naegleriophila & 1300 & -37.05 & 99.79 & 77.86 \\
\hline Leptospirillum ferrodiazotrophum & 1179 & -36.33 & 99.74 & 77.45 \\
\hline Conexibacter woesei & 1128 & -54.7 & 99.04 & 110.35 \\
\hline Amycolatopsis sp. GY182 & 1076 & -34.33 & 100 & 72.67 \\
\hline Nocardioides sp. AL050511-10 & 820 & -44.68 & 99.82 & 91.15 \\
\hline Propionibacterium acnes & 800 & -74.66 & 99.64 & 143.79 \\
\hline Frankia sp. & 785 & -53.45 & 99.48 & 107.5 \\
\hline D. lykanthroporepellens & 616 & -29.24 & 99.97 & 64.3 \\
\hline Rhodopirellula sp. SM49 & 512 & -76.38 & 99.08 & 149.25 \\
\hline Thermoleophilum album & 509 & -54.25 & 99.7 & 107.06 \\
\hline Microbacterium arborescens & 488 & -107 & 99.39 & 199.31 \\
\hline Propionibacterium acidifaciens & 466 & -36.97 & 100 & 77.95 \\
\hline Antarctic soil bacterium 2-1 & 448 & -114.1 & 97.93 & 219.8 \\
\hline Kocuria rhizophila & 397 & -79.08 & 98.53 & 154.58 \\
\hline Atopostipes suicloacalis & 386 & -36.67 & 99.23 & 78.67 \\
\hline
\end{tabular}


Table 1. Cont.

\begin{tabular}{ccccc}
\hline Organism & Abundance & $\begin{array}{c}\text { Avg. eValue } \\
\text { exponent }\end{array}$ & Avg. \% ident. & Avg. align length \\
\hline uncultured alpha proteobacterium & 379 & -62.04 & 99.7 & 120.96 \\
Thermodesulfovibrio islandicus & 366 & -32.29 & 100 & 69.32 \\
Sphaerobacter thermophilus & 347 & -29.59 & 99.76 & 65.23 \\
Lechevalieria aerocolonigenes & 333 & -48.14 & 98.9 & 102.14 \\
Lentzea violacea & 333 & -35.33 & 99.78 & 74.83 \\
Pedosphaera parvula & 328 & -36.62 & 100 & 77.12 \\
unidentified marine eubacterium & 316 & -41.24 & 99.01 & 87.93 \\
Simkania negevensis & 307 & -38.3 & 100 & 79.48 \\
Uncultured $\gamma$ proteobacterium & 303 & -94.04 & 99.83 & 175.23 \\
bacterium culture clone N47 & 280 & -32.28 & 99.69 & 70.6 \\
uncultured soil bacterium & 279 & -57.41 & 99.57 & 113.29 \\
Candidatus Koribacter versatilis & 260 & -51 & 99.8 & 101.57 \\
Acidothermus cellulolyticus & 250 & -48.39 & 99.86 & 96.44 \\
Planctomyces limnophilus & 243 & -34.37 & 100 & 73.11 \\
Desulfothermus naphthae & 241 & -40.8 & 100 & 83.8 \\
Staphylococcus carnosus & 213 & -29 & 100 & 63 \\
Rhodococcus equi & 211 & -30.33 & 100 & 65.67 \\
Thermodesulfobium narugense & 211 & -36.18 & 97.78 & 80.77 \\
\hline
\end{tabular}

\subsection{Greengenes Analysis}

The top matches using the Greengenes database (where abundance was $>800$ sequences or $>1 \%$ of the total sequence number) were to uncultured bacteria (uncultured bacterium 23.4\%, uncultured delta proteobacteria 9.2\%; unassigned 7.1\%; uncultured Dehalococcoides sp. $3.40 \%$; uncultured proteobacteria 3.28\%). The most abundant matches to named groups were: Pirellula staleyi 13.2\%; Rhodopirellula baltica 4.0\%; Spirochaeta aurantia 3.28\%; Spirochaeta thermophila 3.27\%; Streptomyces microflavus 1.8\%; Protochlamydia naegleriophila 1.8\%; Frankia sp. 1.1\%). The Simpsons diversity index was 0.91 for this data set indicating a high diversity. The Chao diversity estimator was 122.8 [50] representing a coverage of $70.8 \%$.

\section{Conclusions}

Cells were detected in Antarctic subglacial lake sediments using DAPI staining and fluorescence in situ hybridization. Viable cells could also be recovered from surface lake sediments through direct culture. However, direct extraction resulted in a relatively low yield of DNA and this could be reflected in the difficulty observing cells directly using SEM. The low biomass made enumeration and characterization challenging, with cell detection at orders of magnitude lower than would be expected for Antarctic surface freshwater lake systems. So a polyphasic approach suggested a relatively low biomass, within the detection limits of some of the assays but not others, indicating sample loss during preparation might be an important issue in DNA extraction and SEM protocols. Importantly, mixed results were obtained across the different methodologies, with consistency in places and not in others (Table 2). In particular, the cultures obtained were represented at the genus level in the 454 data set 
(but not at the species level), FISH hybridizations were consistent with 454 pyrosequencing data for the eubacteria, Alpha-, Beta- and Gammaproteobacteria but not the Actinobacteria, and results from DAPI counts were broadly consistent with FISH counts (Table 2).

Table 2. A comparison of the results from different methodologies.

\begin{tabular}{|c|c|c|}
\hline Culture & FISH & 454 \\
\hline 3x Sporosarcina sp. & LGC354 no hybridization & $\begin{array}{l}\text { Firmicutes } 5.3 \% \text { and } 6 \text { th most abundant sequence } \\
\text { type }\end{array}$ \\
\hline 15x Arthrobacter sp. & HGC263 no hybridization & Actinobacteria $23.8 \%$ most abundant of sequences \\
\hline 2x Streptomyces sp. & HGC263 no hybridization & Actinobacteria $23.8 \%$ most abundant of sequences \\
\hline Present & EUB338 hybridization & Most sequences \\
\hline No culture obtained & ARCH915 no hybridization & Archaea $0.5 \%$ of known sequences \\
\hline No culture obtained & ALF968 hybridization & Alphaproteobacteria $1.2 \%$ of known sequences \\
\hline No culture obtained & GAM42a hybridization & Gammaproteobacteria $5.6 \%$ of known sequences \\
\hline No culture obtained & BET42a hybridization & Betaproteobacteria $0.3 \%$ of known sequences \\
\hline No culture obtained & CF319 hybridization & Bacteroidetes $2.2 \%$ of known sequences \\
\hline No culture obtained & SRB385 no hybridization & Deltaproteobacteria $10.8 \%$ of known sequences \\
\hline No culture obtained & ANME-1-350 no hybridization & Some Archaeal methanogens detected \\
\hline
\end{tabular}

$0.5 \mathrm{~g}$ of sediment generated $250 \mathrm{ng}$ of DNA following extraction. Assuming $2.5 \mathrm{fg}$ DNA cell ${ }^{-1}$, this would be equivalent to $2 \times 10^{8}$ cells $\mathrm{g}^{-1}$ wet sediment. Maximum DAPI counts of $1.22 \times 10^{7}$ to $4.42 \times 10^{7}$ cells g ${ }^{-1}$ wet sediment are broadly in agreement. Elsewhere, cell numbers of $4 \times 10^{9}$ cells g $^{-1}$ (water sediment interface) to $6 \times 10^{7}$ cells $\mathrm{g}^{-1}$ at $40 \mathrm{~cm}$ in a saline high altitude lake [51], $10^{8} \mathrm{cells}^{-1}$ at the surface and $10^{7}$ cells ${ }^{-1}$ were found at $42 \mathrm{~cm}$ in a hypersaline lake [52], $17.7 \times 10^{9} \mathrm{cells} \mathrm{g}^{-1}$ dry

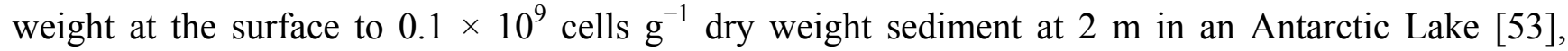
$10^{7}$ cells $\mathrm{g}^{-1}$ have been found in subglacial sediments of the Kamb ice stream [27].

To date, no clear patterns in the biodiversity of exposed Antarctic Lake sediments have been established, the biodiversity reflecting differences in the specific lake type under study (Table 3). However, there are some very general observations, such as the dominance of the Actinobacteria and the Proteobacteria (Gamma and Alpha) and the general lack of Cyanobacteria and Beta-Proteobacteria.

From SSU, RDP and GreenGenes comparisons in this study, the most numerous closest sequence matches were to both marine and soil derived organisms, many of which come from thermophilic environments. Although all were a relatively low fraction of the total, the two most abundant sequence matches were to marine bacteria that are found all over the world: Pirellula staleyi and Rhodopirellula baltica are globally distributed marine bacteria (the former a planctomycete which can also be found in terrestrial habitats) [54]. The second group of frequent matches were to the soil bacteria. Spirochaeta aurantia is an aerobe isolated from mud [55] and Conexibacter woesei is a member of the Actinobacteria isolated from forest soil [56]. The third group could be classified as an extremophile: Spirochaeta thermophila which is extremely thermophilic and marine [57], Thermobaculum terrenum from an extreme thermal soil [58] and Leptospirillum ferrodiazotrophum was isolated from a subsurface acid mine drainage biofilm and is involved in iron oxidation [59]. Further clues about the ecology of the environment could be derived from frequent sequence matches to Frankia - a genus of nitrogen fixing bacteria, Dehalococcoides ethenogenes - which is anaerobic and cannot use inorganic electron 
acceptors [60] and Methylococcus capsulatus, a thermotolerant obligate methanotroph that is able to oxidize some organic hydrogen containing compounds [61].

Table 3. A review of the microbial biodiversity found in Antarctic sediments from different environment types.

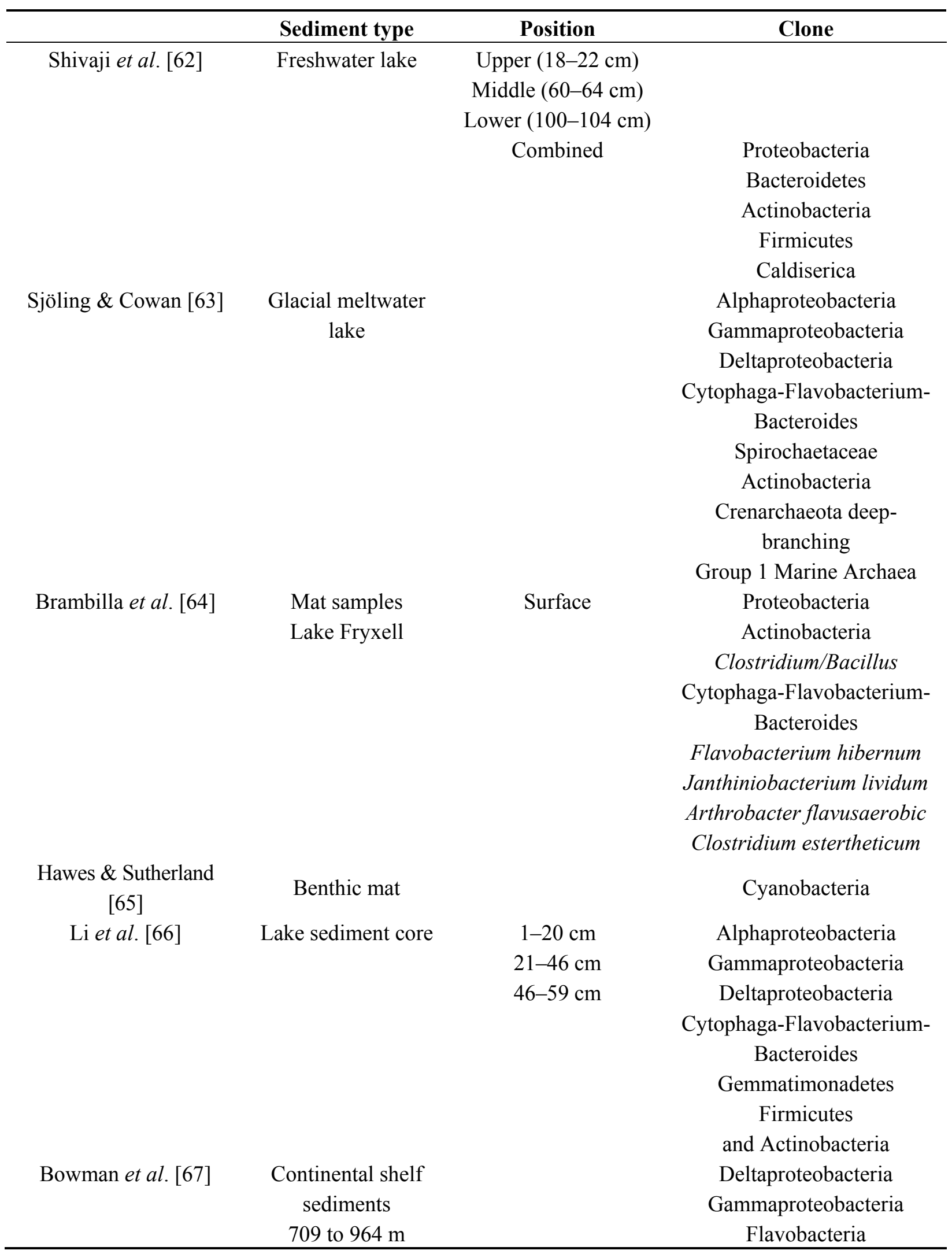


Table 3. Cont.

\begin{tabular}{|c|c|c|c|}
\hline & Sediment type & Position & Clone \\
\hline & & & Planctomycetales \\
\hline & & & Archaea \\
\hline \multirow[t]{4}{*}{ Stackebrandt et al. [68] } & Anaerobic mat & & Firmicutes \\
\hline & Lake Fryxell & & Proteobacteria \\
\hline & & & Bacteriodetes \\
\hline & & & Many novel species \\
\hline \multirow[t]{2}{*}{ Purdy et al. [69] } & Freshwater lake & & Methanosaeta concilii \\
\hline & Heywood & & Limited archaeal diversity \\
\hline \multirow[t]{8}{*}{ Purdy et al. [69] } & Marine Shallow Bay & & Methanolobus \\
\hline & & & Methanococcoides \\
\hline & & & Methanogenium \\
\hline & & & Desulfotalea/Desulforhopalus \\
\hline & & & Desulfofaba \\
\hline & & & Desulfosarcina \\
\hline & & & Desulfobacter \\
\hline & & & Desulfuromonas cluster \\
\hline \multirow[t]{8}{*}{ Bowman et al. [70] } & Meromictic lake & & Low G + C Gram-positive \\
\hline & & & Prochlorococcus \\
\hline & marıne salınity & & Cyanobacteria \\
\hline & anoxic & & Diatom chloroplasts \\
\hline & and a & & Deltaproteobacteria \\
\hline & Marine basin & & Chlamydiales \\
\hline & meromictic & & Spirochaetales \\
\hline & coastal & & Euryarchaeota \\
\hline Chen et al. [71] & Lake and deep sea & & Arthrobacter ardleyensis \\
\hline Wang et al. [72] & Freshwater lake & & $\begin{array}{l}\text { Flavobacterium saliperosum } \\
\text { sp. nov }\end{array}$ \\
\hline \multirow[t]{2}{*}{ Mancuso et al. [53] } & Methanogenic & & \\
\hline & Antarctic Lake & & \\
\hline Karr et al. [73] & Lake Fryxell & & $\begin{array}{l}\text { Two clusters of } \\
\text { methanogens }\end{array}$ \\
\hline
\end{tabular}

\subsection{Microbial Species Diversity}

The origin of sequence matches available were to the full range of bacterial types encountered in natural ecosystems, both habitat specific and cosmopolitan, from terrestrial to aquatic (both freshwater and marine) environments. They also included a number of extremophile groups. These categories included psychrophiles, psychrotolerants, mesophiles, thermophiles and thermotolerants; halophiles, facultative halophiles and non-halophiles; acidophiles and radiotolerants; obligate aerobes, facultative aerobes, aerobes, microaerophiles, facultative anaerobes, aerotolerants, anaerobes and strict anaerobes; spore formers and non-spore formers; filamentous green non-sulfur bacteria and purple non-sulphur bacteria. A diverse range of activities was similarly implied, including: sulphate-reduction, nitrogen fixation, nitrite oxidation, denitrification, methylotrophs, methylobacteria and annamox, elemental 
sulphur removal, antibiotic production, cellulose degradation, oil degradation and C13-C20 hydrocarbon utilization, precipitation of carbonate and activity under high partial pressure of carbon dioxide. Sequence matches were sourced from marine environments (pelagic, sediment, Arctic and extremophilic), freshwater environments (river, Antarctic pond), ubiquitous aquatic and soil (terrestrial, groundwater and compost). There were also representatives from wide ranging environments and extreme habitats (hot springs, hydrothermal vents, deep sea vents, gold mine caves, oil reservoirs, ice wedges and the Yellowstone National Park). Indeed one sequence was related to the most ancient organisms known. However, only $77 \%$ of sequences identified could be matched to a known sequence, species or type strain, suggesting that a vast amount of novel biodiversity is present.

Combining a series of independent PCR amplifications, 454 pyrosequencing gave $\sim 80,000$ valid sequences. On analysis, the information these sequences provided suggested a relatively high proportion of Actinobacteria, Delta- and Gammaroteobacteria, Planctomyctes and Chloroflexi and a comparative dearth of Betaproteobacteria, as seen in Antarctic sediments elsewhere, but the profile of sequences recovered was quite different from surface Antarctic freshwater lake ecosystems. Rather the dominance of the Acidobacteria is somewhat typical of some Antarctic terrestrial ecosystems. Overall, common sequences were neither distinctly polar, low temperature, freshwater nor marine.

There was some evidence from 454 pyrosequencing for the presence of extremophiles in Lake Hodgson. If this proves to be the case, there are several potential sources. The first is that there may be either active or inactive subglacial hydrothermal vent systems nearby as observed in; Jökulhlaup deposits of Southern Iceland [74], Active volcanoes also underlie ice caps in Iceland, glacier-volcano interactions produce meltwater that either drains toward the glacier margin or accumulates in subglacial lakes [75]. This has also been observed at Mount Spurr in Alaska [76]. A hydrothermal contribution to the Vostok subglacial lake (Antarctica) was suggested from bacterial gene analysis and the stable isotope composition of deep ice core samples [77,78]. If this emerging picture is correct, the deep waters of Lake Vostok could harbour an ecosystem fuelled by geochemical energy, much like that observed in deep-sea hydrothermal vent systems [19,79]. A second potential source is indicated through the potential presence of marine sediment, from which a wide variety of extremophiles are regularly isolated [80-82]. A third is the deep biosphere, inoculation from deep within the Earth's crust via fissures and groundwater movements. Marteinsson et al. [18] proposed that the glacial bed is connected through an aquifer in the underlying permeable basalt, and these subglacial lakes may be colonized from a deeper, subterranean microbiome. Fourthly, there are epibionts, commensals and endosymbionts that could be seeded via another organism. The most likely of these scenarios remains to be determined, as we have yet to comprehensively access and fully explore the geological context of this Antarctic subglacial environment.

\subsection{Summary}

The implications of these observations for life in Antarctic subglacial lake ecosystems are that life does indeed occur in the sediments (at least at the continental ice sheet margins where the ice was $c a$. $500 \mathrm{~m}$ thick when the sediments were deposited), some distinct consortia can be identified which include many novel variants of known phyla, the biomass is likely to be relatively low. 
Recommendations for future work on deep continental Antarctic subglacial lakes can also be drawn from this study, such as: (i) life should be detectable with the technologies demonstrated here; (ii) a cell density of $10^{3}$ cells $\mathrm{mL}^{-1}$ in pore water is possible; (iii) $1 \%$ of cells recovered may be amenable to culture (and therefore physiological or biochemical investigation); (iv) not all techniques deployed will give a consistent answer; (v) it should be straightforward to identify dominant groups and (vi) the observed microbial communities will likely be predominantly uncultivated, unstudied and hence potentially new to science. Future studies might include improving resolution through catalysed reporter deposition fluorescence in situ hybridization (CARD-FISH) or multi-locus sequence typing (MLST), direct activity measurements, FISH combined with flow cytometry, subglacial probe target development, microarray analysis and potentially remote sensing.

Hence, the subglacial units in the Lake Hodgson sediment cores have demonstrated that a high diversity of life at relatively low biomass is present in Antarctic subglacial lake sediments, and this will inform which specific groups might be targeted when deeper continental subglacial lakes are accessed. Indeed, both the detection limits and the biodiversity found are encouraging. The generation of 20 cultures indicated the viability of at least a fraction of the microbes found in the Lake Hodgson sediment. So they are clearly distinct ecosystems with huge potential.

\section{Acknowledgments}

We would like to acknowledge Natural Environment Research Council funding through the British Antarctic Survey and the Antarctic Funding Initiative. Field sampling was carried out by DH, Mike Bentley, James Smith and Elie Verleyen. Preliminary analyses of the lake setting and subglacial sediment units were carried out by Stephen Roberts, Mike Bentley, James Smith, Joanne Johnson, Elie Verleyen, Wim Vyverman, Andy Hodson, Melanie Leng, Andreas Cziferszky, Adrian Fox and David Sanderson.

\section{Conflict of Interest}

The authors declare no conflict of interest.

\section{References}

1. Robin, G.D.Q.; Swithinbank, C.W.M.; Smith, M.B.E. Radio echo exploration of the Antarctic ice sheet. In International Symposium on Antarctic Glaciological Exploration (ISAGE); International Association of Scientific Hydrology: Hanover, NH, USA, 1970; Publication number 86, pp. 97-115.

2. Oswald, G.K.A.; Robin, G.D.Q. Lakes beneath Antarctic ice sheet. Nature 1973, 245, 251-254.

3. Siegert, M.J.; Tranter, M.; Ellis-Evans, J.C.; Priscu, J.C.; Lyons, W.B. The hydrochemistry of lake Vostok and the potential for life in Antarctic subglacial lakes. Hydrol. Process. 2003, 17, 795-814.

4. Siegert, M.J.; Carter, S.; Tabacco, I.; Popov, S.; Blankenship, D.D. A revised inventory of Antarctic subglacial lakes. Antarct. Sci. 2005, 17, 453-460.

5. Bell, R.E.; Studinger, M.; Shuman, C.A.; Fahnestock, M.A.; Joughin, I. Large subglacial lakes in East Antarctica at the onset of fast-flowing ice streams. Nature 2007, 445, 904-907.

6. Jones, N. Russians celebrate vostok victory. Nature 2012, doi:10.1038/482287a. 
7. Siegert, M.J.; Clarke, R.J.; Mowlem, M.; Ross, N.; Hill, C.S.; Tait, A.; Hodgson, D.; Parnell, J.; Tranter, M.; Pearce, D.; et al. Clean access, measurement, and sampling of Ellsworth subglacial lake: A method for exploring deep Antarctic subglacial lake environments. Rev. Geophys. 2012, 50, RG1003.

8. Lake Ellsworth Consortium. Exploration of Ellsworth subglacial lake: A concept paper on the development, organisation and execution of an experiment to explore, measure and sample the environment of a West Antarctic subglacial lake. Rev. Env. Sci. Biotechnol. 2007, 6, 1569-1705.

9. Pearce, D.A. Antarctic subglacial lake exploration: A new frontier in microbial ecology. ISME J. 2009, 3, 877-880.

10. Fricker, H.A.; Powell, R.; Priscu, J.; Tulaczyk, S.; Anandakrishnan, S.; Christner, B.; Fisher, A.T.; Holland, D.; Horgan, H.; Jacobel, R.; et al. Siple coast subglacial aquatic environments: The whillans ice stream subglacial access research drilling project. Geophys. Monogr. Ser. 2011, 194, 199-219.

11. Hodgson, D.A.; Roberts, S.J.; Bentley, M.J.; Smith, J.A.; Johnson, J.S.; Verleyen, E.; Vyverman, W.; Hodson, A.J.; Leng, M.J.; Cziferszky, A.; et al. Exploring former subglacial Hodgson Lake, Antarctica paper i: Site description, geomorphology and limnology. Quat. Sci. Rev. 2009, 28, 2295-2309.

12. Schutte, U.M.; Abdo, Z.; Bent, S.J.; Williams, C.J.; Schneider, G.M.; Solheim, B.; Forney, L.J. Bacterial succession in a glacier foreland of the high Arctic.ISME J. 2009, 3, 1258-1268.

13. Anesio, A.M.; Hodson, A.J.; Fritz, A.; Psenner, R.; Sattler, B. High microbial activity on glaciers: Importance to the global carbon cycle. Glob. Chang. Biol. 2009, 15, 955-960.

14. Gaidos, E.; Lanoil, B.; Thorsteinsson, T.; Graham, A.; Skidmore, M.; Han, S.K.; Rust, T.; Popp, B. A viable microbial community in a subglacial volcanic crater lake, Iceland. Astrobiology 2004, 4, 327-344.

15. Miteva, V.I.; Brenchley, J.E. Detection and isolation of ultrasmall microorganisms from a 120,000-year-old Greenland glacier ice core. Appl. Environ. Microbiol. 2005, 71, 7806-7818.

16. Abyzov, S.S.; Hoover, R.B.; Mitskevich, I.N.; Mulyukin, A.L.; Poglazova, M.N.; Rozanov, A.Y. Microbiological Methodology in Astrobiology. Microbial extremophiles: psychrophiles i. In Astrobiology and Planetary Missions, Proceedings of the SPIE 2005, San Diego, CA, USA, 31 July 2005; doi:10.1117/12.618565.

17. Gaidos, E.; Marteinsson, V.; Thorsteinsson, T.; Jóhannesson, T.; Rúnarsson, A.; Stefansson, A.; Glazer, B.; Lanoil, B.; Skidmore, M.; Han, S.; et al. An oligarchic microbial assemblage in the anoxic bottom waters of a volcanic subglacial lake. ISME J. 2009, 3, 486-497.

18. Marteinsson, V.T.; Rúnarsson, Á.; Stefánsson, A.; Thorsteinsson, T.; Jóhannesson, T.; Magnússon, S.H.; Reynisson, E.; Einarsson, B.; Wade, N.; Morrison, H.G.; et al. Microbial communities in the subglacial waters of the Vatnajökull ice cap, Iceland. ISME J. 2013, 7, 427-437.

19. Christner, B.C.; Royston-Bishop, G.; Foreman, C.M.; Arnold, B.R.; Tranter, M.; Welch, K.A.; Berry Lyons, W.; Tsapin, A.I.; Studinger, M.; Priscu, J.C. Limnological conditions in subglacial Lake Vostok, Antarctica. Limnol. Oceanogr. 2006, 51, 2485-2501.

20. D’Elia, T.; Veerapaneni, R.; Rogers, S.O. Isolation of microbes from Lake Vostok accretion ice. Appl. Environ. Microbiol. 2008, 74 4962-4965.

21. D'Elia, T.; Veerapaneni, R.; Theraisnathan, V.; Rogers, S.O. Isolation of fungi from Lake Vostok accretion ice. Mycologia 2009, 101, 751-763. 
22. Rogers, S.O.; Shtarkman, Y.M.S.; Koçer, Z.A.; Edgar, R.; Veerapaneni, R.; D’Elia, T. Ecology of subglacial Lake Vostok (Antarctica), based on metagenomic/metatranscriptomic analyses of accretion ice. Biology 2013, 2, 629-650.

23. Skidmore, M. Microbial communities in Antarctic subglacial aquatic environments (SAE). In Exploration and Study of Antarctic Subglacial Aquatic Environments; Siegert, M.J.; Kennicutt II, M.C.; Bindschandler, R.A. Ed.; ACU Press: Washington, DC, USA, 2011; AGU Geophysical Monograph Series, Volume 192, pp. 61-81.

24. Bulat, S.A.; Alekhina, I.A.; Lipenkov, V.Y.; Lukin, V.V.; Marie, D.; Petit, J.R. Cell concentrations of microorganisms in glacial and lake ice of the vostok ice core, east antarctica. Microbiology 2009, 78, 808-810.

25. Priscu, J.C.; Adams, E.E.; Lyons, W.B.; Voytek, M.A.; Mogk, D.W.; Brown, R.L.; McKay, C.P.; Takacs, C.D.; Welch, K.A.; Wolf, C.F.; et al. Geomicrobiology of subglacial ice above Lake Vostok, Antarctica. Science 1999, 286, 2141-2144.

26. Christner, B.C.; Mosley-Thompson, E.; Thompson, L.G.; Reeve, J.N. Isolation of bacteria and 16s RDNAs from Lake Vostok accretion ice. Environ. Microbiol. 2001, 3, 570-577.

27. Lanoil, B.; Skidmore, M.; Priscu, J.C.; Han, S.; Foo, W.; Vogel, S.W.; Tulaczyk, S.; Engelhardt, H. Bacteria beneath the West Antarctic ice sheet. Environ. Microbiol. 2009, 11, 609-615.

28. Hodgson, D.A.; Roberts, S.J.; Bentley, M.J.; Carmichael, E.L.; Smith, J.A.; Verleyen, E.; Vyverman, W.; Geissler, P.; Leng, M.J.; Sanderson, D.C.W. Exploring former subglacial Hodgson Lake, Antarctica. Paper ii: Palaeolimnology. Quat. Sci. Rev. 2009, 28, 2310-2325.

29. Porter, K.G.; Feig, Y.S. The use of DAPI for identifying and counting aquatic microflora. Limnol. Oceanogr. 1980, 25, 943-948.

30. Amann, R.I.; Binder, B.J.; Olson, R.J.; Chisholm, S.W.; Devereux, R.; Stahl, D.A. Combination of 16S RNA-targeted oligonucleotide probes with flow cytometry for analyzing mixed microbial populations. Appl. Environ. Microbiol. 1990, 56, 1919-1925.

31. Stahl, D.A. Development and application of nucleic acid probes. In Nucleic Acid Techniques in Bacterial Systematics; Stackebrandt, E., Ed.; John Wiley \& Sons Ltd.: Chichester, UK, 1991; pp. 205-248.

32. Manz, W.; Amann, R.; Ludwig, W.; Wagner, M.; Schleifer, K.H. Phylogenetic oligodeoxynucleotide probes for the major subclasses of proteobacteria-problems and solutions. Syst. Appl. Microbiol. 1992, 15, 593-600.

33. Glockner, F.O.; Fuchs, B.M.; Amann, R. Bacterioplankton compositions of lakes and oceans: A first comparison based on fluorescence in situ hybridization. Appl. Environ. Microbiol. 1999, 65, 3721-3726.

34. Manz, W.; Amann, R.; Ludwig, W.; Vancanneyt, M.; Schleifer, K.H. Application of a suite of 16S RNA-specific oligonucleotide probes designed to investigate bacteria of the phylum CytophagaFlavobacter-Bacteroides in the natural environment. Microbiol. UK 1996, 142, 1097-1106.

35. Boetius, A.; Ravenschlag, K.; Schubert, C.J.; Rickert, D.; Widdel, F.; Gieseke, A.; Amann, R.; Jorgensen, B.B.; Witte, U.; Pfannkuche, O. A marine microbial consortium apparently mediating anaerobic oxidation of methane. Nature 2000, 407, 623-626.

36. Glockner, F.O.; Zaichikov, E.; Belkova, N.; Denissova, L.; Pernthaler, J.; Pernthaler, A.; Amann, R. Comparative 16S RNA analysis of lake bacterioplankton reveals globally distributed phylogenetic 
clusters including an abundant group of Actinobacteria. Appl. Environ. Microbiol. 2000, 66, 5053-5065.

37. Meier, H.; Amann, R.; Ludwig, W.; Schleifer, K.H. Specific oligonucleotide probes for in situ detection of a major group of Gram-positive bacteria with low DNA G + C content. Syst. Appl. Microbiol. 1999, 22, 186-196.

38. Wallner, G.; Amann, R.; Beisker, W. Optimizing fluorescent in situ hybridization with RNA-targeted oligonucleotide probes for flow cytometric identification of microorganisms. Cytometry 1993, 14, 136-143.

39. Herrera, A.; Cockell, C.S.; Self, S.; Blaxter, M.; Reitner, J.; Arp, G.; Drose, W.; Thorsteinsson, T.; Tindle, A.G. Bacterial colonization and weathering of terrestrial obsidian in Iceland. Geomicrobiol. J. 2008, 25, 25-37.

40. Cockell, C.S.; Olsson, K.; Knowles, F.; Kelly, L.; Herrera, A.; Thorsteinsson, T.; Marteinsson, V. Bacteria in weathered basaltic glass, iceland. Geomicrobiol. J. 2009, 26, 491-507.

41. Mergeay, M.; Nies, D.; Schlegel, H.G.; Gerits, J.; Charles, P.; van Gijsegem, F. Alcaligenes eutrophus $\mathrm{CH} 34$ is a facultative chemolithotroph with plasmid-bound resistance to heavy metals. J. Bacteriol. 1985, 162, 328-334.

42. Ryan, F.J. Selected methods of neurospora genetics. Methods Med. Res. 1950, 3, 51-75.

43. Geneious homepage. Available online: http://www.geneious.com (accessed on 1 July 2013)

44. Schloss, P.D.; Gevers, D.; Westcott, S.L. Reducing the effects of PCR amplification and sequencing artifacts on 16S RNA-based studies. PloS One 2011, 6, e27310.

45. Gomez-Alvarez, V.; Teal, T.K.; Schmidt, T.M. Systematic artifacts in metagenomes from complex microbial communities. ISME J. 2009, 3, 1314-1317.

46. Meyer, F.; Paarmann, D.; D’Souza, M.; Olson, R.; Glass, E.M.; Kubal, M.; Paczian, T.; Rodriguez, A.; Stevens, R.; Wilke, A.; et al. The metagenomics rast server-a public resource for the automatic phylogenetic and functional analysis of metagenomes. BMC Bioinforma. 2008, 9, 386:1-386:8.

47. Pruesse, E.; Quast, C.; Knittel, K.; Fuchs, B.M.; Ludwig, W.; Peplies, J.; Glockner, F.O. Silva: A comprehensive online resource for quality checked and aligned ribosomal RNA sequence data compatible with arb. Nucleic Acids Res. 2007, 35, 7188-7196.

48. DeSantis, T.Z.; Hugenholtz, P.; Larsen, N.; Rojas, M.; Brodie, E.L.; Keller, K.; Huber, T.; Dalevi, D.; $\mathrm{Hu}$, P.; Andersen, G.L. Greengenes, a chimera-checked 16S RNA gene database and workbench compatible with arb. Appl. Environ. Microbiol. 2006, 72, 5069-5072.

49. Cole, J.R.; Wang, Q.; Cardenas, E.; Fish, J.; Chai, B.; Farris, R.J.; Kulam-Syed-Mohideen, A.S.; McGarrell, D.M.; Marsh, T.; Garrity, G.M.; et al. The ribosomal database project: Improved alignments and new tools for RNA analysis. Nucleic Acids Res. 2009, 37, D141-D145.

50. Chao, A. Nonparametric-estimation of the number of classes in a population. Scand. J. Stat. 1984, 11, 265-270.

51. Dong, H.; Zhang, G.; Jiang, H.; Yu, B.; Chapman, L.R.; Lucas, C.R.; Fields, M.W. Microbial diversity in sediments of saline Qinghai Lake, China: Linking geochemical controls to microbial ecology. Microb. Ecol. 2006, 51, 65-82. 
52. Jiang, H.; Dong, H.; Zhang, G.; Yu, B.; Chapman, L.R.; Fields, M.W. Microbial diversity in water and sediment of Lake Chaka, an athalassohaline lake in Northwestern China. Appl. Environ. Microbiol. 2006, 72, 3832-3845.

53. Mancuso, C.A.; Franzmann, P.D.; Burton, H.R.; Nichols, P.D. Microbial community structure and biomass estimates of a methanogenic Antarctic lake ecosystem as determined by phospholipid analyses. Microb. Ecol. 1990, 19, 73-95.

54. Glockner, F.O.; Kube, M.; Bauer, M.; Teeling, H.; Lombardot, T.; Ludwig, W.; Gade, D.; Beck, A.; Borzym, K.; Heitmann, K.; et al. Complete genome sequence of the marine planctomycete Pirellula sp. Strain 1. Proc. Natl. Acad. Sci. USA 2003, 100, 8298-8303.

55. Breznak, J.A.; Canale-Parola, E. Spirochaeta aurantia, a pigmented, facultatively anaerobic spirochete. J. Bacteriol. 1969, 97, 386-395.

56. Monciardini, P.; Cavaletti, L.; Schumann, P.; Rohde, M.; Donadio, S. Conexibacter woesei gen. Nov., sp. Nov., a novel representative of a deep evolutionary line of descent within the class actinobacteria. Int. J. Syst. Evol. Microbiol. 2003, 53, 569-576.

57. Aksenova, H.Y.; Rainey, F.A.; Janssen, P.H.; Zavarzin, G.A.; Morgan, H.W. Spirochaeta-thermophila sp-nov, an obligately anaerobic, polysaccharolytic, extremely thermophilic bacterium. Int. J. Syst. Bacteriol. 1992, 42, 175-177.

58. Botero, L.M.; Brown, K.B.; Brumefield, S.; Burr, M.; Castenholz, R.W.; Young, M.; McDermott, T.R. Thermobaculum terrenum gen. nov., sp. nov.: A non-phototrophic gram-positive thermophile representing an environmental clone group related to the chloroflexi (green non-sulfur bacteria) and thermomicrobia. Arch. Microbiol. 2004, 181, 269-277.

59. Tyson, G.W.; Lo, I.; Baker, B.J.; Allen, E.E.; Hugenholtz, P.; Banfield, J.F. Genome-directed isolation of the key nitrogen fixer Leptospirillum ferrodiazotrophum sp. nov. From an acidophilic microbial community. Appl. Environ. Microbiol. 2005, 71, 6319-6324.

60. Maymo-Gatell, X.; Anguish, T.; Zinder, S.H. Reductive dechlorination of chlorinated ethenes and 1, 2-dichloroethane by "Dehalococcoides ethenogenes" 195. Appl. Environ. Microbiol. 1999, 65, 3108-3113.

61. Ward, N.; Larsen, O.; Sakwa, J.; Bruseth, L.; Khouri, H.; Durkin, A.S.; Dimitrov, G.; Jiang, L.; Scanlan, D.; Kang, K.H.; et al. Genomic insights into methanotrophy: The complete genome sequence of Methylococcus capsulatus (bath). PLoS Biol. 2004, 2, e303.

62. Shivaji, S.; Kumari, K.; Kishore, K.H.; Pindi, P.K.; Rao, P.S.; Radha Srinivas, T.N.; Asthana, R.; Ravindra, R. Vertical distribution of bacteria in a lake sediment from antarctica by culture-independent and culture-dependent approaches. Res. Microbiol. 2011, 162, 191-203.

63. Sjoling, S.; Cowan, D.A. High 16S RDNA bacterial diversity in glacial meltwater lake sediment, Bratina Island, Antarctica. . Extremophiles 2003, 7, 275-282.

64. Brambilla, E.; Hippe, H.; Hagelstein, A.; Tindall, B.J.; Stackebrandt, E. 16S RDNAdiversity of cultured and uncultured prokaryotes of a mat sample from Lake Fryxell, Mcmurdo Dry Valleys, Antarctica. . Extremophiles 2001, 5, 23-33.

65. Sutherland, D.L.; Hawes, I. Annual growth layers as proxies of past growth conditions for benthic microbial mats in a perennially ice-covered Antarctic lake. FEMS Microbiol. Ecol. 2009, 67, 279-292. 
66. Li, S.; Xiao, X.; Yin, X.; Wang, F. Bacterial community along a historic lake sediment core of Ardley Island, West Antarctica. . Extremophiles 2006, 10, 461-467.

67. Bowman, J.P.; McCammon, S.A.; Gibson, J.A.; Robertson, L.; Nichols, P.D. Prokaryotic metabolic activity and community structure in Antarctic continental shelf sediments. Appl. Environ. Microbiol. 2003, 69, 2448-2462.

68. Stackebrandt, E.; Brambilla, E.; Cousin, S.; Dirks, W.; Pukall, R. Culture-independent analysis of bacterial species from an anaerobic mat from Lake Fryxell, Antarctica: Prokaryotic diversity revisited. Cell. Mol. Biol. 2004, 50, 517-524.

69. Purdy, K.J.; Nedwell, D.B.; Embley, T.M. Analysis of the sulfate-reducing bacterial and methanogenic archaeal populations in contrasting Antarctic sediments. Appl. Environ. Microbiol. 2003, 69, 3181-3191.

70. Bowman, J.P.; Rea, S.M.; McCammon, S.A.; McMeekin, T.A. Diversity and community structure within anoxic sediment from marine salinity meromictic lakes and a coastal meromictic marine basin, Vestfold Hills, eastern Antarctica. Environ. Microbiol. 2000, 2, 227-237.

71. Chen, M.; Xiao, X.; Wang, P.; Zeng, X.; Wang, F. Arthrobacter ardleyensis sp. nov., isolated from Antarctic Lake sediment and deep-sea sediment. Arch. Microbiol. 2005, 183, 301-305.

72. Wang, Z.W.; Liu, Y.H.; Dai, X.; Wang, B.J.; Jiang, C.Y.; Liu, S.J. Flavobacterium saliperosum sp. nov., isolated from freshwater lake sediment. Int. J. Syst. Evol. Microbiol. 2006, 56, 439-442.

73. Karr, E.A.; Ng, J.M.; Belchik, S.M.; Sattley, W.M.; Madigan, M.T.; Achenbach, L.A. Biodiversity of methanogenic and other archaea in the permanently frozen Lake Fryxell, Antarctica. Appl. Environ. Microbiol. 2006, 72, 1663-1666.

74. Farmer, J.D.; Warner, N.H. Subglacial hydrothermal alteration minerals in jökulhlaup deposits of southern iceland, with implications for detecting past or present habitable environments on Mars. Astrobiology 2010, 10, 523-547.

75. Bjornsson, H. Subglacial lakes and jokulhlaups in Iceland. Glob. Planet. Change 2002, 35, 255-271.

76. Garchar, L.; Wendlandt, R.; Martini, B.; Owens, L. Geochemistry of a sub glacial volcanic hydrothermal system at Mount Spurr, Alaska, Proceedings of Thirty Seventh Workshop on Geothermal Reservoir Engineering Stanford, Stanford, CA, USA, 30 January-1 February 2012.

77. Petit, J.R.; Alekhina, I.A.; Bulat, S.A. A hydrothermal contribution to the Vostok subglacial lake (Antarctica) suggested from bacterial gene analysis and the stable isotope composition of deep ice core samples, Proceedings of 35th COSPAR Scientific Assembly, Paris, France, 18-25 July 2004; p. 832.

78. Lavire, C.; Normand, P.; Alekhina, I.; Bulat, S.; Prieur, D.; Birrien, J.-L.; Fournier, P.; Hänni, C.; Petit, J.-R. Presence of Hydrogenophilus thermoluteolus DNA in accretion ice in the subglacial Lake Vostok, Antarctica, assessed using rrs, cbb and hox. Environ. Microbiol. 2006, 8, 2106-2114.

79. Parkes, R.J.; Cragg, B.A.; Wellsbury, P. Recent studies on bacterial populations and processes in subseafloor sediments: A review. Hydrogeol. J. 2000, 8, 11-28.

80. Park, B.-J.; Park, S.-J.; Yoon, D.-N.; Schouten, S.; Sinninghe Damsté, J.S.; Rhee, S.-K. Cultivation of autotrophic ammonia-oxidizing archaea from marine sediments in coculture with sulfur-oxidizing bacteria. Appl. Environ. Microbiol. 2010, 76, 7575-7587. 
81. Mathis, B.J.; Marshall, C.W.; Milliken, C.E.; Makkar, R.S.; Creager, S.E.; May, H.D. Electricity generation by thermophilic microorganisms from marine sediment. Appl. Microbiol. Biotechnol. 2008, 78, 147-155.

82. Li, H.; Yu, Y.; Luo, W.; Zeng, Y.; Chen, B. Bacterial diversity in surface sediments from the Pacific Arctic Ocean. Extremophiles 2009, 13, 233-246.

(C) 2013 by the authors; licensee MDPI, Basel, Switzerland. This article is an open access article distributed under the terms and conditions of the Creative Commons Attribution license (http://creativecommons.org/licenses/by/3.0/). 